\title{
Trace Elements in Cherry Salmon (Oncorhynchus masou) in the Southwestern Part of the Sea of Okhotsk
}

\author{
Nadezhda K. Khristoforova ${ }^{1,2}$, Anna V. Litvinenko ${ }^{3}$, Vasily Yu. Tsygankov ${ }^{1,4}$, and Maxim V. Kovalchuk ${ }^{5}$ \\ ${ }^{1}$ School of Natural Sciences, Far Eastern Federal University, Vladivostok 690091, Russia \\ ${ }^{2}$ Pacific Institute of Geography, Far Eastern Branch, Russian Academy of Sciences, Vladivostok 690041, Russia \\ ${ }^{3}$ Sakhalin State University, Yuzhno-Sakhalinsk 693008, Russia \\ ${ }^{4}$ School of Biomedicine, Far Eastern Federal University, Vladivostok 690091, Russia \\ ${ }^{5}$ LLC “RN-SakhalinNIPImorneft", Yuzhno-Sakhalinsk, 693000, Russia
}

Keywords: Pacific salmon, cherry salmon, Oncorhynchus masou, trace elements, Sea of Okhotsk, southeast coast of Sakhalin

\section{Introduction}

The Far Eastern shores of Russia are washed by three large seas - the Bering, Okhotsk, and Sea of Japan - as well as the waters of the northwestern Pacific. Marine and oceanic waters of the western Pacific are exceptionally rich in aquatic biological resources - fish, sea animals, invertebrates, algae, and seagrasses. Concerning fish abundance, the main contribution is made by pelagic objects - pollock, herring, sardine-ivasi, and Pacific salmon.

Salmon of the west Pacific exist in many groups, each manifesting in places of wintering, feeding, and spawning. A special area during anadromous and catadromous migrations of salmon is the Kuril-Kamchatka region, which is known as an oceanic biogeochemical province, and as a highly productive water area used for feeding by many salmon groups. Passing through this geochemically impacted region, salmon, together with food (plankton), accumulate various chemical elements in their tissues significantly enriching their mineral composition. At the same time, a considerable number of salmon groups do not winter in the ocean, but spend their winters in the Sea of Japan without crossing the Kuril ridge and the Kuril-Kamchatka trench. Therefore, the study of the mineral composition of salmon tissues makes it possible to clarify the routes of their migration and the possible region of their ocean residency and feeding more definitively. In addition, knowledge of the levels of trace elements in the tissues of important food items, such as Pacific salmon, is also necessary from a sanitary and hygienic standpoint.

The Sakhalin-Kuril region is one of the main salmon-catching areas in the Russian Far East. The main objects of fishing and artificial breeding in the Sakhalin region are chum salmon (Oncorhynchus keta) and pink salmon (Oncorhynchus gorbuscha). Masu salmon (Oncorhynchus masou) are endemic to the Asian coast; however, the majority of their range is located in the Sea of Japan basin and the southern Sea of Okhotsk (South Kuril Islands, Sakhalin Island, Hokkaido and Honshu Islands, Amur River). The most numerous masu salmon populations live in the rivers of Primorye, the Tatar Strait, Sakhalin (especially the southwestern and southern coasts), Hokkaido, the northern part of Honshu, Sakhalin Bay (Amur and its tributaries), and western Kamchatka (Birman 1986; Bugaev et al. 2007; Omelchenko et al. 1991; Semenchenko 1989).

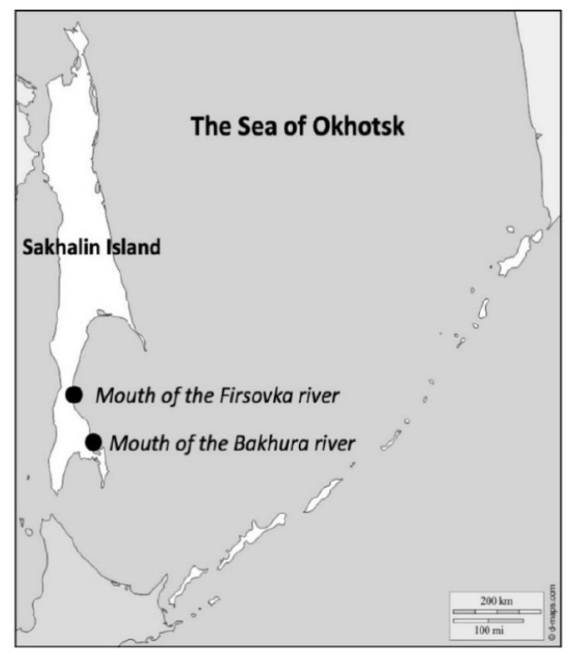

Fig. 1. Sampling locations on Sakhalin Island. 
Spawners of both masu salmon and pink salmon came to spawn off the southeastern coast of Sakhalin and were caught in the mouths of the closely located Bakhura and Firsovka rivers flowing into the Gulf of Patience. The sampling locations are shown in Fig. 1.

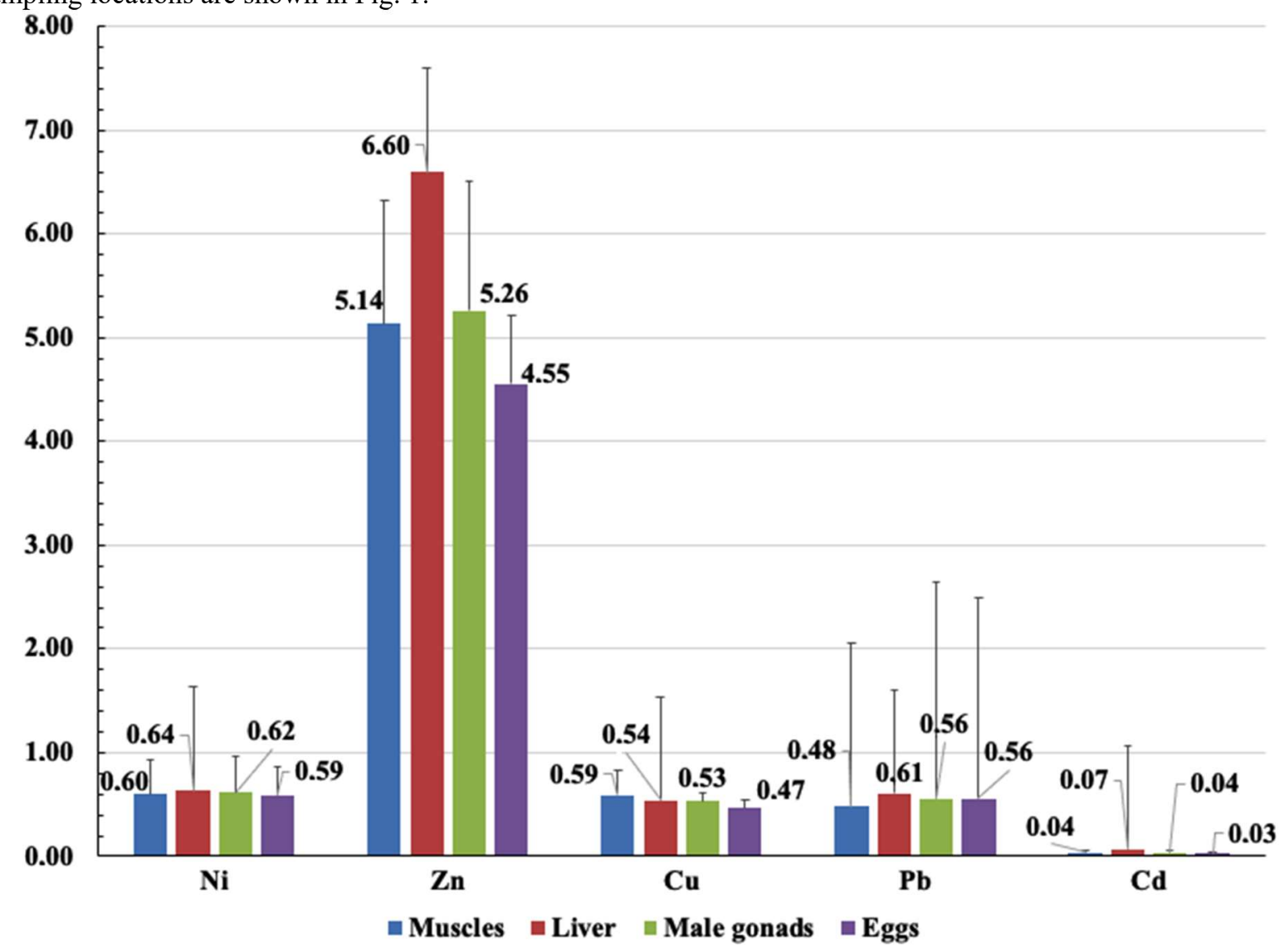

Fig. 2. Concentration $\mathrm{Ni}, \mathrm{Zn}, \mathrm{Cu}, \mathrm{Pb}$, and $\mathrm{Cd}$ in organs of a masu salmon from the Bakhura River (mg/kg wet weight).

\section{Materials and methods}

We collected the masu salmon specimens in the summer of 2017 at the mouth of the Bakhura River, pink salmon spawners in the fall of 2018 at the mouth of the Firsovka River. Ten individuals (five females and five males) were taken; muscle tissue, liver, and gonads were taken from all sampled individuals and frozen before delivery to Vladivostok for chemical analysis. All elements were determined in samples after acid mineralization, carried out in the laboratory microwave system MARS 6, according to National State Standard 26929-94 (National State Standard 2010). The analysis was performed on a Shimadzu AA 6800 atomic absorption spectrophotometer in the geochemical laboratory of the Pacific Geographical Institute of the Far Eastern Branch of the Russian Academy of Science: $\mathrm{Zn}, \mathrm{Cu}$, and $\mathrm{Ni}-\mathrm{in}$ a flame; $\mathrm{Pb}$ and $\mathrm{Cd}$ - in a graphite furnace. The accuracy of determining the elemental composition, as well as possible contamination of the samples during analysis was controlled by a comparison with calibration solutions, including an empty (zero) solution. The accuracy and precision of the method used have been confirmed by regular analysis of the standard reference material SRM-1566a. The results of the analysis for the content of trace elements in the organs and tissues of fish are presented in $\mu \mathrm{g} / \mathrm{g}$ wet weight and are shown in Fig. 2. The mean, standard deviation, and significance of the compared differences (using the MannWhitney U test) were calculated using SPSS Statistics 21 software for MacOSX.

\section{Results and discussion}

The results of the analysis are presented in Fig. 2, which shows the concentrations of trace elements in the organs and tissues of a masu salmon from the Bakhura River. 


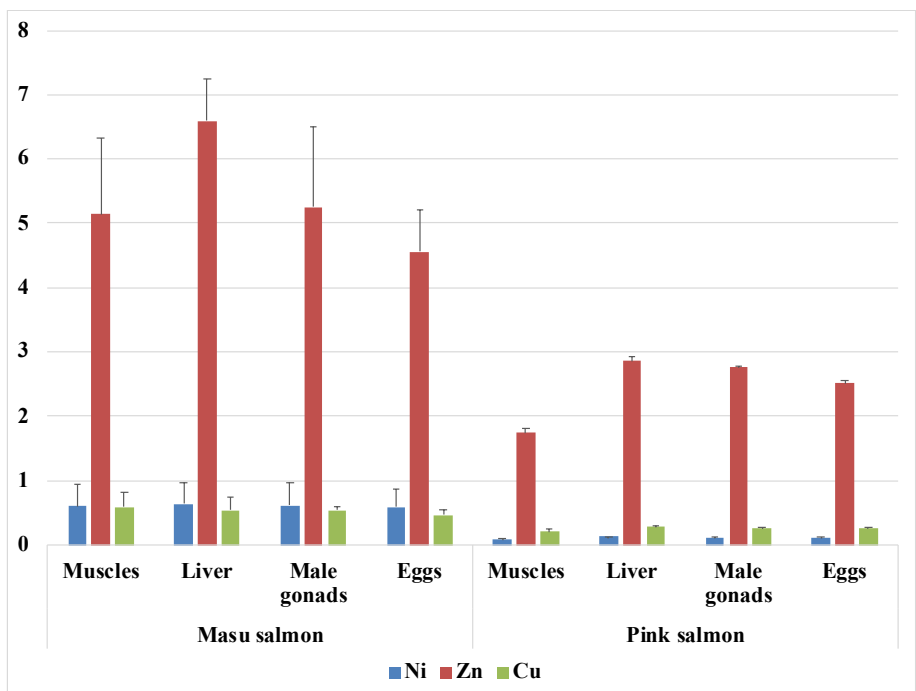

Fig. 3. Concentration of $\mathrm{Ni}, \mathrm{Zn}, \mathrm{Cu}$ in organs of masu salmon from the Bakhura River and pink from the Firsovka River (mg/kg wet weight).

When deciding which elements to analyze, we chose elements that have a negative impact on the environment and organisms. It should be emphasized that $\mathrm{Zn}$ and $\mathrm{Cu}$ are, as a rule, indicators of the flow of household wastewater and discharge of bilge water from ships. Lead $(\mathrm{Pb}), \mathrm{Cd}$, and $\mathrm{Ni}$ are indicators of technogenic impact and the latter two elements, especially nickel, enter the marine environment mainly through the combustion of hydrocarbon fuels (Khristoforova et al. 2015; Khristoforova et al. 2019a; Khristoforova et al. 2019b). As you can see, zinc strongly prevails over other elements, and this is typical for the entire biosphere. Iron and zinc were the first and main chemical elements in the emerging microelement composition of the biota (Boychenko 1976). Copper, nickel, and lead are found in masu salmon in close and noticeable amounts, while cadmium is clearly a minor element. A comparison of the content of zinc, copper, and nickel in organs and tissues of fish of both species shows an obvious predominance of these elements in masu salmon (Fig. 3). The organs and tissues of pink salmon from the Firsovka River, on the other hand, are markedly dominated by the content of $\mathrm{Pb}$ and $\mathrm{Cd}$ (Fig. 4).

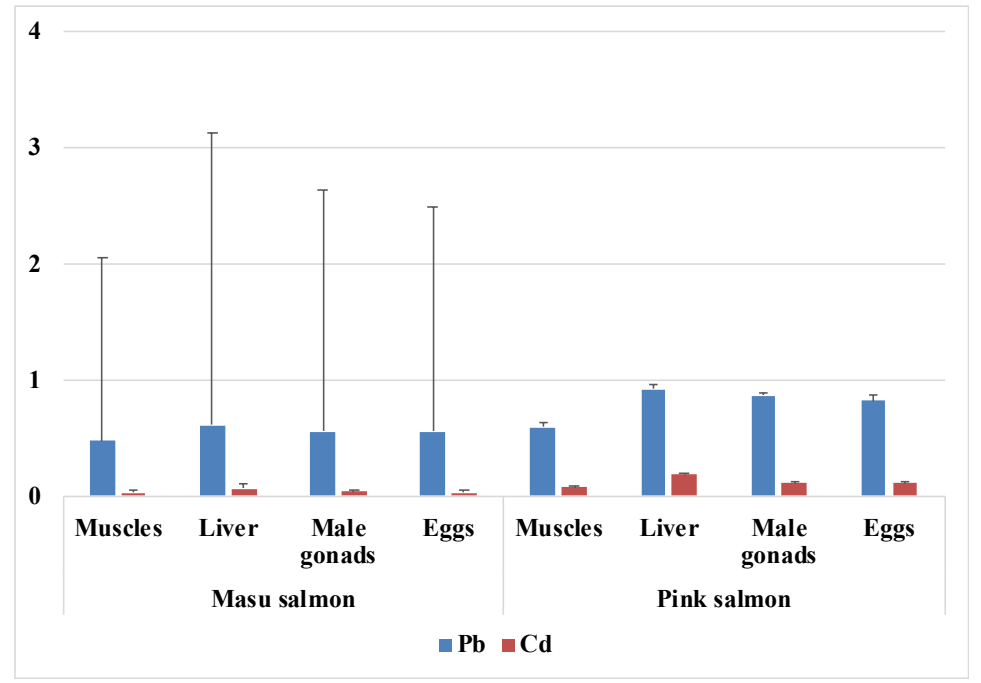

Fig. 4. Concentration $\mathrm{Pb}$ and $\mathrm{Cd}$ in organs of masu salmon from the Bakhura River and pink salmon from the Firsovka River (mg/kg wet weight).

Differences in element concentrations could be explained by biological and environmental characteristics of masu salmon. Oncorhynchus masou is a species of Pacific salmon with a long freshwater period. Smoltification and drift in the sea for most masu salmon occurs after one or two years of life in the river. In Japan, the southern part of Sakhalin, and the south of Primorye - the southern range of masu salmon — most juveniles migrate in the second year and return to spawn after one winter at sea. The marine part of the masu's range, like the feeding area, is limited to Asian waters. Masu salmon is mainly a marine species (Atlas 2002; Masuda et al. 1984; Shuntov and Temnykh 2011). The juveniles of the Sea of Japan stocks mainly enter the waters of the southern basin of the Sea of Okhotsk for feeding (Shuntov and Temnykh 2008). Most of the salmon leave the Sea of Okhotsk during November 
and during winter and autumn-summer migrations, they are found throughout the water area of the Sea of Japan, where they intensively feed and consume small fish. Most of the mature individuals enter the Sea of Okhotsk through the La Perouse Strait and partially penetrate through the southern Kuril straits. Masu are mainly caught in May when they pass through the open waters of the southern part of the Russian economic zone in the Sea of Japan. Off the southwestern coast of Sakhalin, in catches by set nets, the fishing peak occurs at the end of May, and more rarely in the first half of June. By the mid-end of June, catches decline (Shuntov and Temnykh 2011).

Migration of masu to rivers, in general, occurs much earlier than other species of Pacific salmon. Its spawning grounds overlap little with other species and it ripens for two or three months before spawning (Semenchenko 1989). Thus, the masu caught by us could form a microelement composition that is more consistent with the technogenic and anthropogenic influence $(\mathrm{Zn}, \mathrm{Cu}, \mathrm{Ni})$ from both, one-two years of life in the river (before downstream migration to the sea) and during a two-three month stay in a spawning river.

\section{Conclusion}

Finally, we came to understand the reasons for the differences in the microelement composition of masu salmon and pink salmon that spawn in the rivers of Southeastern Sakhalin. Pink salmon fed in the waters near the Kuril Islands of the northwestern part of the Pacific Ocean, having passed through the impact geochemical zone twice (first when entering the ocean for wintering, then during the return migration for spawning from the ocean to the rivers of the Sea of Okhotsk), accumulating noticeably greater amounts of elements such as $\mathrm{Pb}$ and $\mathrm{Cd}$, supplied to the environment by volcanism and upwellings.

Masu salmon, being not oceanic but a marine species due to the peculiarities of its biology and ecology, during its life cycle accumulates microelements in organs and tissues, which are more consistent with technogenic and anthropogenic influences $(\mathrm{Zn}, \mathrm{Cu}, \mathrm{Ni})$.

\section{REFERENCES}

Atlas of distribution in the sea of various stocks of Pacific salmon during spring-summer feeding and pre-spawning migrations. 2002. Moscow: VNIRO. 190 pp. (In Russian)

Birman, I.B. 1986. Marine life and issues of dynamics of Pacific salmon herds. Agropromizdat, Moscow. 208 pp. (In Russian)

Boychenko, E.A. 1976. The participation of metals in the evolution of plants in the biosphere. Izv. Academy of Sciences of the USSR. Ser. Biol. No. 3: 378-385. (In Russian)

Bugaev, V.F., B.B. Vronsky, L.O. Zavarina, et al. 2007. Fish of the Kamchatka River (abundance, trade, problems). KamchatNIRO, Petropavlovsk-Kamchatsky. 496 pp. (In Russian)

Khristoforova, N.K., V. Yu. Tsygankov, M.D. Boyarova, O.N. Lukyanova. 2015. The content of trace elements in the Pacific and Atlantic salmon. Oceanology. 55(5): 751-758.

Khristoforova, N.K., A.V. Litvinenko, V.Yu. Tsygankov, M.V. Kovalchuk, and N.I. Erofeeva. 2019a. Trace elements content in the pink salmon (Oncorhynchus Gorbuscha Walbaum, 1792) from Sakhalin-Kuril region. N. Pac. Anadr. Fish Comm. Tech. Rep. 15: 59-62. (Available at https://npafc.org)

Khristoforova, N.K., A.V. Litvinenko, V.Yu. Tsygankov, M.V. Kovalchuk, and N.I. Erofeeva. 2019b. Microelement composition of pink salmon Oncorhynchus Gorbuscha (Walbaum, 1792) from the SakhalinKuril region. Russ. J. Mar. Biol. 45(3): 221-227.

Masuda, H., K. Amaoka, C. Araga, T. Uyeno, and T. Yoshino. 1984. The fishes of the Japanese Archipelago. Vol. 1. Tokai University Press, Tokyo. $437 \mathrm{pp}$.

National State Standard GOST 26929-94. Raw materials and food products. Sample preparation. Mineralization to determine the content of toxic elements. 2010. Standartinform, Moscow. 12 pp.

Omelchenko, V.T., T.V. Malinina, and V.V. Tsygir. 1991. Population structure of Oncorhynchus masou (Brev.): Genetic and biochemical study of populations in the southern part of Primorye. Russian Journal of Genetics (Genetic) 2: 290-298. (In Russian)

Semenchenko, A.Yu. 1989. Seaside masu. Population ecology, morphology, reproduction. Dalnauka, Vladivostok. 192 pp. (In Russian)

Shuntov, V.P., and O.S. Temnykh. 2008. Pacific salmon in marine and oceanic ecosystems: a monograph. TINRO-Center, Vladivostok. 481 pp. (In Russian)

Shuntov, V.P., and O.S. Temnykh. 2011. Pacific salmon in marine and oceanic ecosystems: a monograph. TINRO-Center, Vladivostok. 473 pp. (In Russian) 